\title{
Characteristics of Ultramafic Igneous Rock Ofiolite Complex in Asera District, North Konawe Regency, Southeast Sulawesi Province, Indonesia
}

\author{
Hasria $^{1 *}$, Erzam S. Hasan ${ }^{2}$, Deniyatno ${ }^{3}$, L M Iradat Salihin ${ }^{4}$ \\ Asdiwan ${ }^{1}$ \\ ${ }^{1}$ Department of Geological Engineering, Halu Oleo University, Kendari, Indonesia \\ 2 Department of Geophysical Engineering, Halu Oleo University, Kendari, Indonesia \\ 3 Department of Mining Engineering, Halu Oleo University, Kendari, Indonesia \\ ${ }^{4}$ Department of Geography, Halu Oleo University, Kendari, Indonesia
}

* Corresponding author : hasriageologi@gmail.com

Tel : +62 852-4158-7853

Received: Nov 25, 2019; Accepted: Apr 27, 2020.

DOI:10.25299/jgeet.2020.5.3.4113

\begin{abstract}
The research area is located in Asera District, North Konawe Regency, Southeast Sulawesi Province which has ultramafic rock lithology. The purpose of this study is to determine the characteristics of ultramafic igneous rocks using petrographic and geochemical analysis. Petrographic analysis aims to determine the types and abundance of minerals present so that rock types can be determined based on the classification of Travis (1955) and Streckeisen (1976). The geochemical analysis aims to determine the oxide/major element so that it can determine the type of magma based on the AFM classification according to Irvine and Baragar (1971) and the origin of the magma / original rock formation environment based on Pearce (1977). Petrographic analysis results showed that ultramafic rocks in the study area consisted of 2 types of rocks namely peridotite consisting of wherlit and lherzoite and serpentinite. The results of geochemical analysis indicate that the type of magma in the study area is thoellitic series and the origin of the magma/rock formation environment comes from the expansion of the oceanic floor or mid oceanig ridge (MOR) which is ultramafic.
\end{abstract}

Keywords: Asera, North Konawe, Ultramafic, petrography, geochemistry

\section{Introduction}

The opiolite and pelagic sedimentary rocks in the East and Southeast Arm of Sulawesi are called the East Sulawesi Ophiolite Belt. This belt consists of mafic and ultramafic rocks accompanied by pelagic and melange sedimentary rocks in several places. Ultramafic is dominant in the Southeastern Arm, but the mafic rocks are dominant further north, especially along the North coast of the Southeast Arm of Sulawesi. Complete opiolite sequences are found in the Eastern Arm, including mafic and ultramafic rocks, pillow lava and pelagic sedimentary rocks which are dominated by deep sea limestone and layered cherry intercalation (Surono, 2013).

In the geological map of the Kendari Lasusua Sheet with a scale of 1: 250,000 (Rusmana et al., 1993), the Asera District of North Konawe Regency, Southeast Sulawesi Province (Figure 1) is on the Opiolite $(\mathrm{Ku})$ Mandala line of eastern Sulawesi in the lime age. The constituent rocks in the Opiolite $\mathrm{Ku})$ lane are harzburgite, lhezorlit, wehrlit, websterite, serpentinite, dunit, and gabro rocks. These rocks are rocks which, if weathered, can form nickel laterite in lateralization processes which are generally composed of mafic minerals with low silica $\left(\mathrm{SiO}_{2}\right)$ content of less than $45 \%$ (Ahmad, 2002).

The constituent minerals of ultramafic igneous rocks are olivine, pyroxene and hornblende which are in a fresh state is dark colour. Decomposition of these primary minerals which causes the elements carried in the solution will then precipitate at a certain place. This process runs dynamically and slowly, so that the laterite profile is formed which is the development of the laterization stages.

\section{Research Methods}

The method used in this study is divided into four stages namely: (1) Desk Study, (2) fieldwork (3) laboratory analysis and (4) data interpretation.

\subsection{Desk Study}

At this stage secondary data collection and literature review of the results of previous studies were carried out relating to the geological conditions of the study area.

\subsection{Fieldwork}

Field work includes surface geology observation and mapping and representative sampling, geomorphological observations and geological structures.

\subsection{Laboratory Analysis}

This analysis includes petrography and geochemistry. Petrographic analysis begins with sample preparation into thin sections, then analyzed using a Nikon type polarization microscope. Petrographic analysis aims to determine the types and abundance of minerals present so that rock types can be determined based on the classification of Travis (1955) and Streckeisen (1976). The geochemical analysis aims to determine the oxide / major element so that it can determine the type of magma based on the AFM classification according to Irvine and Baragar (1971) and the origin of the magma / original rock formation environment based on Pearce (1977). Petrographic analysis was carried out at the Geological Engineering Laboratory of the Faculty of Earth Sciences and 
Technology of Halu Oleo University and geochemical analysis in the form of XRF (X-Ray Fluoresence) analysis was carried out at PT. Minertech Indonesia.

\subsection{Data Interpretation}

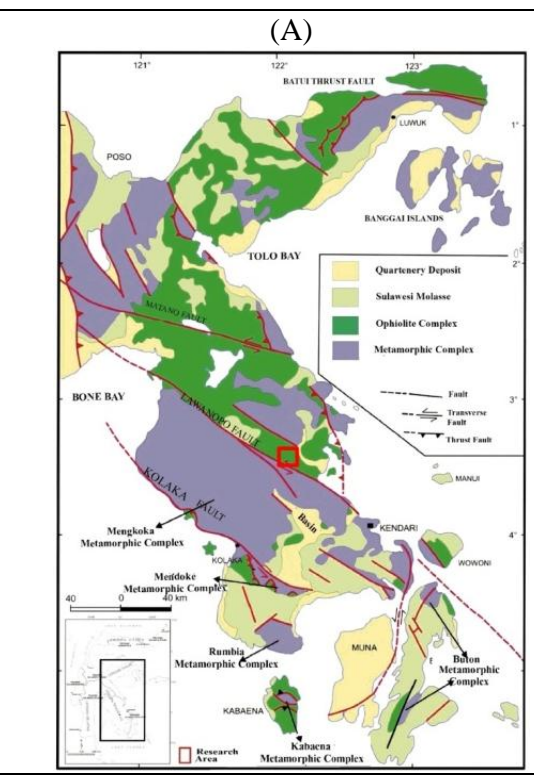

Fig 1. (A) Regional geology of the study area (modified from Surono, 2013).

(B) Characteristics of ultramafic rocks in the study area.

\section{Results and Discussion}

The number of stations in this study was 13 stations (Figure 1B), but there were 8 representative samples analyzed by petrography. After petrographic analysis, geochemical analysis is then performed based on petrographic analysis.

\subsection{Characteristics of Ultramafic Rocks}

\subsubsection{Ultramafic Rock Petrography}

The interpretation of the data in this study includes all relevant data from the results of field and laboratory work which are evaluated and compiled to produce research objectives.

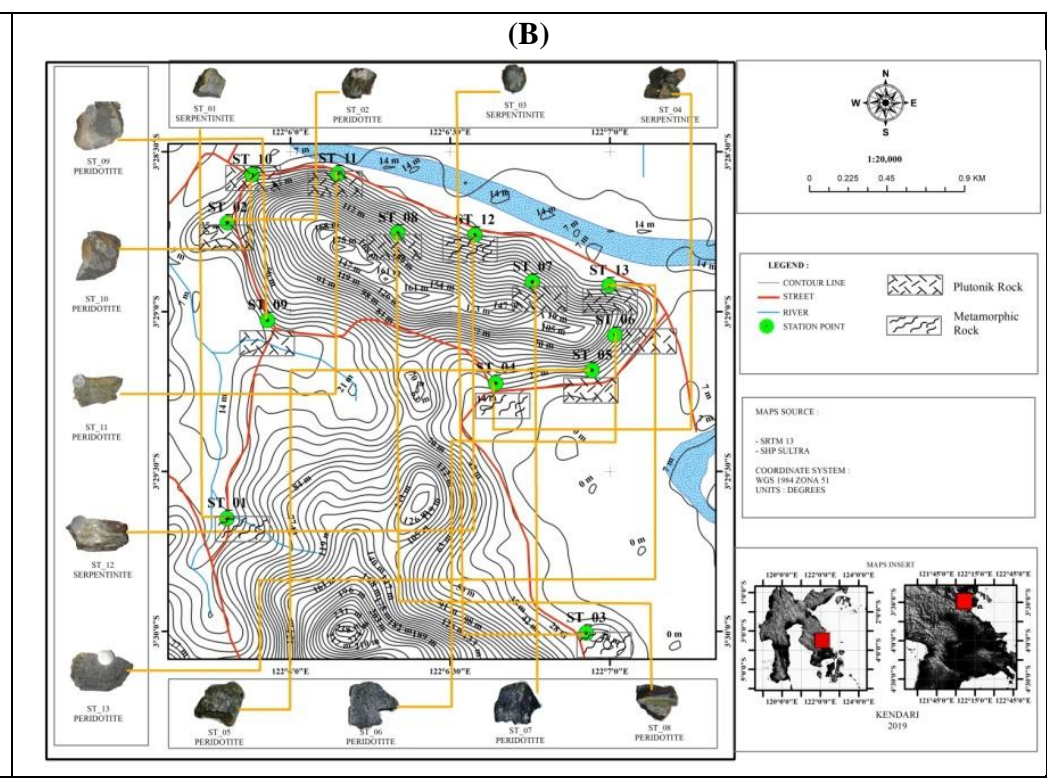

Table 1. Characteristics of ultramafic rocks based on petrographic analysis

\begin{tabular}{|c|c|c|c|c|c|c|c|}
\hline \multirow[b]{2}{*}{ Rock group } & \multicolumn{5}{|c|}{ Mineral content $(\%)$} & \multirow[b]{2}{*}{ Rock Name } & \multirow[b]{2}{*}{ Sample Code } \\
\hline & $\begin{array}{c}\text { Ol } \\
(\%)\end{array}$ & Opx (\%) & $\begin{array}{l}\text { Cpx } \\
(\%)\end{array}$ & $\begin{array}{l}\text { Srp } \\
(\%)\end{array}$ & $\begin{array}{c}\text { Opq } \\
(\%)\end{array}$ & & \\
\hline Peridotite & 50 & 10 & 30 & - & 10 & Wherlit & ST_05 \\
\hline Peridotite & 45 & 20 & 25 & - & 10 & Lhezorlit & ST_02 \\
\hline Peridotite & 45 & 15 & 32 & 5 & 2 & Lhezorlit & ST_06 \\
\hline Peridotite & 43 & 35 & 15 & & 7 & Lhezorlit & ST_07 \\
\hline Peridotite & 40 & 20 & 32 & 5 & 3 & Lhezorlit & ST_08 \\
\hline Serpentinit & 5 & - & - & 90 & 5 & Serpentinit & ST_01 \\
\hline Serpentinit & - & - & - & 95 & 5 & Serpentinit & ST_03 \\
\hline Serpentinit & 10 & - & 25 & 65 & - & Serpentinit & ST_04 \\
\hline
\end{tabular}

\section{A. Peridotit Group}

Generally rocks in the study area are included in the peridotite group. Based on the results of petrographic analysis, peridotite rock types are divided into 2, namely wherlit (ST_05) and lhezorlit (ST_02,ST_06,ST_7 and ST_08) (Streckeisen, 1976). The two rock types are distinguished by the presence of olivine, orthopiroxen and clinopiroksen minerals present in peridotite rocks.

\section{i). Wherlit}

Petrographic analysis results on ST_05 showed that the mineral composition in rock samples consisted of $50 \%$ olivine minerals, $10 \%$ orthopiroxene minerals, $30 \%$ klinopiroxen and $10 \%$ opaque minerals (Figure 2).

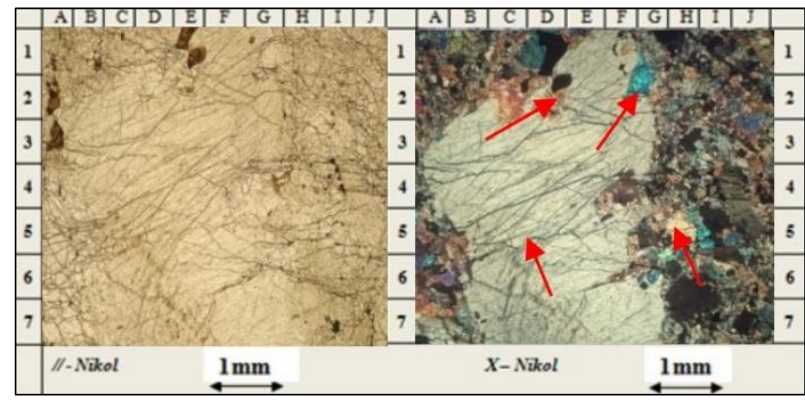

Fig 2. Microscopic appearance of sample point ST_05. Olivine mineral (Ol), orthopiroxen mineral (Opx), klinopiroxen mineral (Cpx) and Opaque mineral (Opq). 
The results of ploting using the Streckeisen (1976) classification of mineral compositions (Figure 2) show that the characteristics of ultramafic rocks at this station include wherlite rock types (Figure 3).

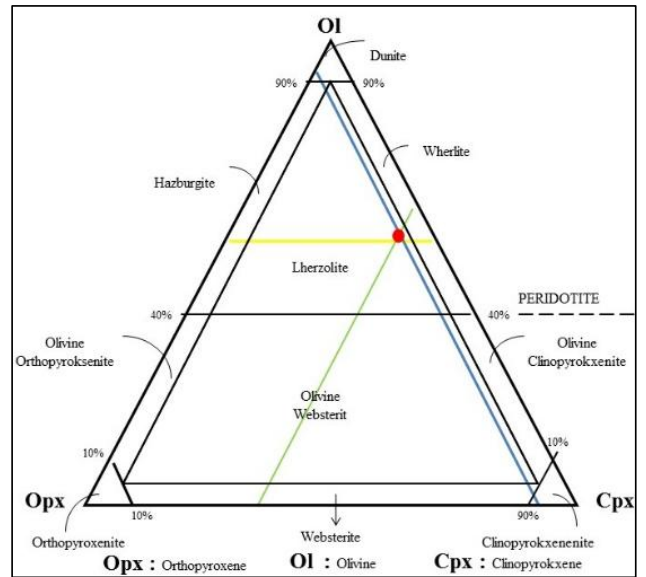

Fig 3. Classification of ultramafic rocks according to Streckeisen (1976).

\section{ii). Lhezorlit}

Petrographic analysis results on ST_02 showed that the mineral composition in rock samples consisted of $45 \%$ olivine minerals, $20 \%$ orthoproxene minerals, $25 \%$ klinopiroxen and $10 \%$ opaque minerals (Figure 4 ).

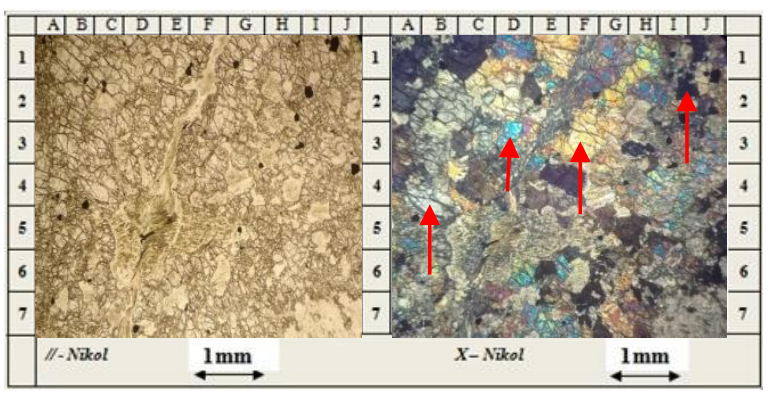

Fig 4. Microscopic appearance of sample point ST_02. The minera olivine $(\mathrm{Ol})$, ortho-pyroxene mineral (Opx), clinopiroxen mineral (Cpx) and Opak mineral (Opq).

The results of ploting using the Streckeisen (1976) classification of mineral compositions (Figure 4) show that the characteristics of ultramafic rocks at this station include lherzoite rock types (Figure 5). The same characteristics of ultramafic rock in the form of lherzoites are also found in ST_06 ST_07 and ST_08 (Table 2).

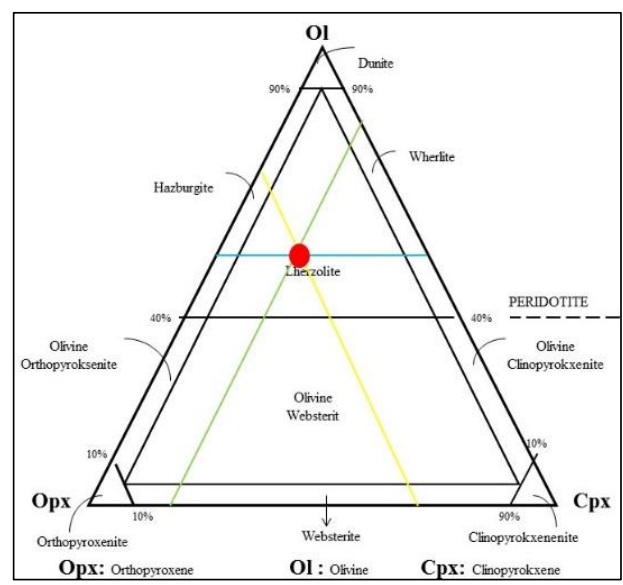

Fig 5. Classification of ultramafic rocks according to Streckeisen (1976).

\section{B. Serpentinite Group}

The serpentine group is based on the presence of abundant serpenitite minerals with a little extra mineral olivine and pyroxene and opaque minerals. The serpentine mineral is formed from the chemical changes of the olivine and pyroxene minerals so that it undergoes the serpentinization process.

Petrographic analysis results on ST_01 showed that the mineral composition in rock samples consisted of $90 \%$ serpentine minerals, 5\% olivine minerals and 5\% opaque minerals (Figure 6).

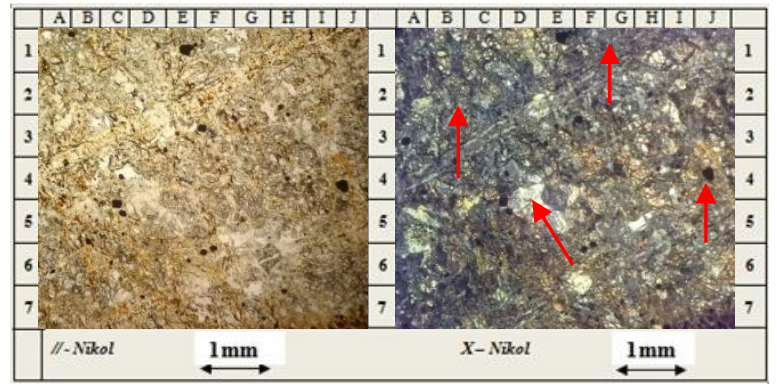

Fig 6. Microscopic appearance of sample point ST_01. Serpentin (Srp) mineral, olivine (Ol), orthopiroxen mineral (Opx), and Opaque mineral (Opq).

Figure 6 shows that the mineral serpentine with a $90 \%$ mineral percentage generally fills fractures in minerals due to the structure that works, and the effect of alteration that converts the minerals olivine and pyroxene into serpentine minerals. Petrographic observations show that opaque minerals whose presence is around 5\% are thought to be chromite minerals. The results of the analysis show that the rocks at this station have been serpentinized into serpentinic rocks. Referring to the abundance of serpentine minerals in rocks, the characteristics of ultramafic rocks at this station include serpentine type ultramafic rocks (Travis, 1955). Serpentine type ultramafic rocks are also found in ST_04 in the presence of 65\% serpentine minerals, $10 \%$ olivine minerals and $25 \%$ clinopiroxen minerals (Table 2).

Table 2. Oxides/constituent elements of ultramafic rocks Asera District North Konawe Regency Southeast Sulawesi Province.

\begin{tabular}{|c|c|c|}
\hline \multirow{4}{*}{ Elements } & \multicolumn{2}{|c|}{ Rock Name } \\
\hline & Peridotite & Serpentinit \\
\hline & \multicolumn{2}{|c|}{ Sample Code } \\
\hline & ST_02 & ST_04 \\
\hline $\mathrm{Fe}$ & $6,281(\mathrm{wt} \%)$ & $5,027(\mathrm{wt} \%)$ \\
\hline $\mathrm{Co}$ & $0,02(\mathrm{wt} \%)$ & j,007 (wt\%) \\
\hline $\mathrm{Ni}$ & $0,319(\mathrm{wt} \%)$ & ),291 (wt\%) \\
\hline $\mathrm{Al}_{2} \mathrm{O}_{3}$ & $1,298(\mathrm{wt} \%)$ & $1,692(\mathrm{wt} \%)$ \\
\hline $\mathrm{SiO}_{2}$ & $37,82(\mathrm{wt} \%)$ & $38,119(\mathrm{wt} \%)$ \\
\hline $\mathrm{Cao}$ & $1,79(\mathrm{wt} \%)$ & $2,114(\mathrm{wt} \%)$ \\
\hline Mgo & 29,749 (wt\%) & $30,112(\mathrm{wt} \%)$ \\
\hline $\mathrm{Cr}_{2} \mathrm{O}_{3}$ & $0,243(\mathrm{wt} \%)$ & $0,451(\mathrm{wt} \%)$ \\
\hline Mno & $0,159$ (wt $\%)$ & J,219 (wt\%) \\
\hline $\mathrm{Fe}_{2} \mathrm{O}_{3}$ & $7,219(\mathrm{wt} \%)$ & $7,62(\mathrm{wt} \%)$ \\
\hline $\mathrm{Na}_{2}$ & $0,017(w t \%)$ & J,019 (wt\%) \\
\hline $\mathrm{Al}$ & $0,208(w t)$ & J,019 (wt) \\
\hline $\mathrm{Ca}$ & $0,627(\mathrm{wt} \%)$ & $1,694(\mathrm{wt} \%)$ \\
\hline $\mathrm{Mn}$ & $0,033(\mathrm{wt} \%)$ & j,068 (wt\%) \\
\hline $\mathrm{P}$ & $0,003(w t \%)$ & ),003 (wt \%) \\
\hline$S$ & $0,038(\mathrm{wt} \%)$ & ),013 (wt \%) \\
\hline $\mathrm{Cr}$ & $0,269(\mathrm{wt} \%)$ & J,236 (wt\%) \\
\hline $\mathrm{K}_{2} \mathrm{O}$ & $0,009(\mathrm{wt} \%)$ & $0,005(\mathrm{wt} \%)$ \\
\hline
\end{tabular}

\section{Determination of the Types and Origins of magma}

\section{i). The main element of ultramafic rocks}

The determination of the oxide / main element of ultramafic rocks in the study area was carried out on 2 samples 
representing rock units contained in the study area, namely the peridotite rock group and the serpentinite rock group that had been previously performed petrographic analysis to determine the mineral content contained in the rock. Geochemical analysis is carried out to determine the oxides / main elements contained in these ultramafic rocks. The results of geochemical analysis showed that the oxide / element content in both samples was low $\mathrm{SiO}_{2}$ with 37.82 (wt\%) and 38.119 (wt\%) content. The content of $\mathrm{SiO}_{2}, \mathrm{Al}_{2} \mathrm{O}_{3}$, and $\mathrm{K}_{2} \mathrm{O}$ is quite low while the content of $\mathrm{MgO}$ and $\mathrm{FeO}$ and $\mathrm{Fe}_{2} \mathrm{O}_{3}$ is quite high (Table 2). The high content of $\mathrm{MgO}$ and the low content of $\mathrm{SiO}_{2}$ are the characteristics of ultramafic rocks, where ultramafic rocks are rich in magnesium and iron minerals and low in silica (Rollinson, 1993). Following are the results of the analysis of the main elements carried out by PT. Minertech Indonesia (Table 2).

\section{ii). Types of Magma}

Based on the results of the geochemical analysis in the form of XRF, the types of magma plotted on the AFM diagram (Irvine and Baragar, 1971) on the ultramafic rocks in the study area are included in the tholeiitic series (Figure 7).

This type is very common in tectonic settings in the form of ocean floor expansion zones or commonly referred to as mid ocenic ridge (MOR) (Wilson, 1989). This is characterized by low $\mathrm{SiO}_{2}$ and $\mathrm{K}_{2} \mathrm{O}$ values and rich in ferromagnetic compositions such as $\mathrm{MgO}$ and $\mathrm{FeO}$ (Table 2).

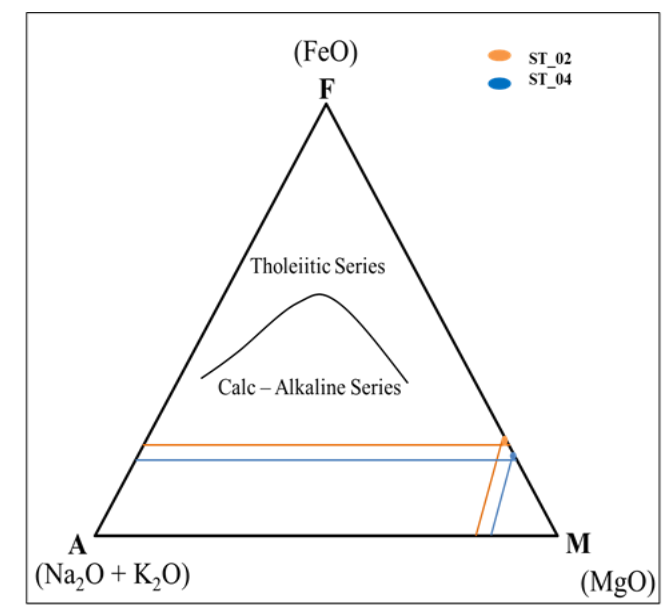

Fig 7. Plotting results in the classification of types of magma according to (Irvine and Baragar 1971).

The types of magma consist of two groups, namely alkaline and subalkalin. These alkaline rocks are rich in alkaline and are usually not saturated with silica while subalkalin rocks are saturated with silica. This subalkalin group is divided into two groups namely thoellitic series and cal-alkaline series.

Thoellitic rocks are more rich in Fe compared to $\mathrm{MgO}$ than cal-alkaline rocks and generally have less silica variation. The calc-alkaline group shows more silica and alkali enrichment Magma series describes the spatial variation of magma. The farther from the trench that is formed, the type of magma is transformed into thoellitic, then calc-alkaline is getting farther away becoming alkaline (Wilson, 1989).

The classification of magma types is based on the content of the main elements in rocks in the form of $\mathrm{K}_{2} \mathrm{O}+\mathrm{Na}_{2} \mathrm{O}, \mathrm{FeO}$ and $\mathrm{MgO}$ elements, which are plotted into the AFM triangle (Irvine and Baragar, 1971) (Figure 8), so based on these results and the results of petrographic and geochemical analysis, then the research area has a type of magma that is thoellitic Series which is ultramafic.

\section{iii). Origin of Magma}

The origin of magma forming ultramafic igneous rocks in the study area can be determined using the Pearce triangle diagram, 1977, which is based on the comparison of the main elements of ultramafic rocks in the form of $\mathrm{FeO}, \mathrm{MgO}$, and $\mathrm{Al}_{2} \mathrm{O}_{3}$ elements. Based on the triangle diagram, the tectonic setting of ultramafic rocks in the study area is included in oceanic ridge and floor, or mid oceanic ridge (MOR) (Figure 8).

Based on the results of geochemical analysis on ultramafic rock samples in the study area, ultramafic rocks have a $\mathrm{K}_{2} \mathrm{O}$ value of less than 0.1 so it can be concluded that the type of MOR that forms these rocks is the normal type (type $\mathrm{N}$ ). Type $\mathrm{N}$ or normal type MORs are formed at shallow depths, which are between $60-80 \mathrm{~km}$ from the upper mantle (Wilson, 1989). $\mathrm{K}_{2} \mathrm{O}$ value is used for this interpretation because the value of the element is at least in the MOR.

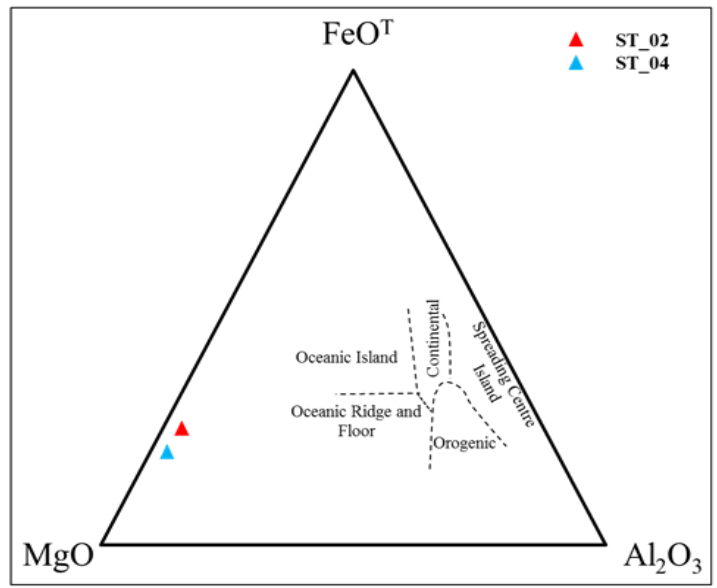

Fig 8. Results of ploting on the classification of the origin of magma according to (Pearce, 1977).

Based on research conducted by several experts including Surono 2013, Robert Hall, 2012 that opiolites in the Southeast Arm of Sulawesi were formed in an ocean floor expansion environment (MOR). By referring to this matter, which is supported by petrographic data and geochemical data, it can be interpreted that the research location was formed due to ocean floor expansion (MOR). The formation process first takes place in the mid-ocean expansion, followed by the movement of material originating from the mantle in accordance with the movement of the expansion. Based on the results of the withdrawal of absolute age by Surono (2010) on pelagic sedimentary rocks in the Eastern Arm of Sulawesi, the ultramafic rocks revealed in the East Arm and Southeast Arm of Sulawesi have Late Cretaceous age. Based on these, the ultramafic rocks in the Southeast Arm of Sulawesi might form in the Late Cretaceous which is marked by the rifting process. Southeast Sulawesi experienced a drift from the Australian Continent moving towards Sulawesi's current position (Hall, 2012). Based on the reconstruction carried out (Hall, 2012) shows that Southeast Sulawesi is part of the Australian Continent which is currently in the Southeast part of Sulawesi Island.

Hall (2012) estimates that the expansion of the ocean floor that occurred in the Late Cretaceous caused rocks that characterize the oceanic floor to form. This process was followed by the movement of the Australian Continent towards Eurasia / Sundaland which was accommodated by India Australia Transform. The subduction process began at the Beginning of Paleocene on the edge of Sundaland. This subduction caused the movement of the Australian Continent to move towards Eurasia. In addition, the subduction also led to the formation of North Sulawesi Province which is an archipelago formed (Hall, 2012). The subduction process stops 
at the Late Oligocene and there is initial contact between Sula Spur and the North Sulawesi Archipelago Bow. This subduction process continues and causes collision events in the Early Miocene which causes the ocean floor to rise to form the foreland basin. This collision event is often also referred to as soft collision. As a result of the continued subduction process, the second collision event occurred at the Pliocene, known as a hard collision between the results of the first collision (Sula Spur and the North Sulawesi Archipelago Bow) and Eurasia / Sundaland which formed Sulawesi as seen today (Hall, 2012).

Based on this concept and the results of petrographic and geochemical analysis, the rock area is ultramafic, with a type of magma thoellitic series and is formed in the oceanic ridge area (Best, 2003; Pearce, 1977 Pearce et al, 1984), which is the ocean bloom zone (MOR) originating from the Australian continent which was exposed to the surface due to the collision process forming Sulawesi as seen today (Hall, 2012)

\section{Conclusions}

Based on petrographic analysis that the characteristics of ultramafic rocks in the study area consisted of 2 groups namely peridotite groups consisting of wherlit and lherzoite and serpentinite groups. Petrographic results supported by geochemical data indicate that the type of magma in the study area shows thoellitic series based on the percentage of the main elements in the form of $\mathrm{FeO}, \mathrm{Na}_{2} \mathrm{O}+\mathrm{K}_{2} \mathrm{O}$ and $\mathrm{MgO}$ plotted in the AFM triangle. The origin of the magma / rock formation environment in the study area is the oceanic ridge and floor expansion (MOR) based on the percentage of main elements in the form of $\mathrm{FeO}, \mathrm{MgO}$, and $\mathrm{Al}_{2} \mathrm{O}_{3}$.

\section{Acknowledgements}

This study was made possible through the financial support from Research Institute of Halu Oleo University. The authors are very thankful to Head Research Institute of Halu Oleo University forfacility assistance during field fieldwork. Thanks to Head Asera District which has given permission to do.Special thanks to my students from Department of Geological Engineering, Halu Oleo University for their assistance during the fieldwork

\section{References}

Ahmad, W., 2002, Nickel Laterites-A Short Course : Chemistry, Mineralogy, and Formation of Nickel
Laterites ( unpublished ), $98 \mathrm{p}$.

Best, M., G., 2003, Igneous and Metamorphic Petrology 2nd Edition, Blackwell Publishing Company, Australia.

Hall, R. 2012. Late Jurassic-Cenozoic Reconstruction of the Indonesian Region and the Indian Ocean. Tectonophysics 570-571, 1- 41 .

Irvine, T.N and Baragar, W.R.A., 1971. A Guide to the chemical classification of the common volcanic rock. Canadian Journal of Earth Science 8,523-248.

Pearce T,H, Gorman B,E and Birkett T.C. 1977. The relationship between major element chemistry and tectonic environment of basic and intermediate volcanic rocks, Earth Planet Sci

Pearce, J.A., Lippard, S.S., Roberts, S.,1984. Characteristics and tectonic significance of suprasubduction zone ophiolites. In: Kokelaar, B.P., Howells, M.F. (Eds.), Marginal Basin Geology. Volcanic and Associated Sedimentary and Tectonic Processes in Modern and Ancient Marginal Basins Geological Society of London Special Publication, vol.16, pp. 77-94.

Rollinson, H., 1993., Using Gheocemical data : Evaluation, Presentation and Interpretation, longman grup, UK

Rusmana E., Sukido, Sukarna, D., Haryanto E. \& Simandjuntak T.O., 1993 Geological Map of Lasusua Sheet - Kendari, Sulawesi, scale 1: 250,000, Center for Geological Research and Development, Bandung.

Streckeisen, A.L., 1976, Classification of The Common Igneous Rocks by Means of Their Chemical Composition: A Provosional Attempt, Neues Jahrbuch For Mineralogie, Monatshhefte.

Surono 2013. Geology of Southeast arm Sulawesi. Center for Geological Research and Development.

Surono. 2010. Geologi Lengan Tenggara Sulawesi. Publikasi Khusus, Badan Geologi, KESDM, 161p.

Travis, B.R.,1995. The Rock Book. New York. Quarterly of the Colorapdo School of Mines.

Wilson, M. 1989. Igneous petrogenesis a global tectonic Approach. Chapman \& Hall.

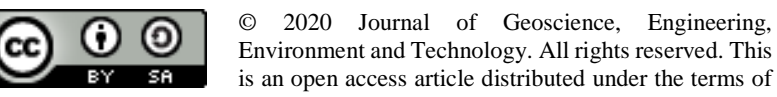
the CC BY-SA License (http://creativecommons.org/licenses/by-sa/4.0/). 